International Journal of Agriculture and Environmental Research

ISSN: 2455-6939

Volume: 06, Issue: 02 "March-April 2020"

\title{
EVALUATION OF GENES ASSOCIATED WITH MASTITIS IN CROSSBRED DAIRYCATTLE
}

\author{
${ }^{1 *}$ Daniel. CV. Tarbal; ${ }^{1}$ Joseph. O. Jung'a; ${ }^{1}$ Rawlynce. C. Bett \\ ${ }^{1}$ Department of Animal Production, College of Agriculture and Veterinary Sciences, \\ University of Nairobi, P.O. Box 29053 - 00625 Kangemi, Nairobi \\ *Corresponding author
}

DOI: 10.46609/IJAER.2020.v06i02.008 URL: https://doi.org/10.46609/IJAER.2020.v06i02.008

\begin{abstract}
Mastitis affects dairy production economically. It also associated with increased somatic cells in milk, these cells include; neutrophils, macrophages, lymphocytes, and mammary epithelial cells. They are used as an indicator to monitor udder health status of dairy cattle. Somatic cell count has higher heritability as compared to mastitis, thus it can be used as a trait for selection of mastitis resistance. The objective of this study was to evaluate genes associated with mastitis in crossbred dairy cattle. Blood samples were collected from 96 crossbred cattle for DNA analysis, and a total of 152 milk samples were collected from full udder quarters of 38 lactating crossbred dairy cattle for SCC analysis. Genomic DNA of beta-lactoglobulin and lactoferrin genes were amplified using two pairs of oligo primers 252 bp and 301 bp respectively. Their amplified products yielded 27 fragments at the 301-bp and 23 fragments at 252-bp. Results of PCR-DNA sequencing found out that there were several genetic variations in sequences, which were identified as Single Nucleotide Polymorphism (SNPs) associated with mastitis susceptibility. This study strongly suggests that beta-lactoglobulin and lactoferrin are novel candidate genes for selection of mastitis resistance in crossbred dairy cattle.
\end{abstract}

Keywords: Crossbred, Gene, Mastitis, Somatic Cell Count, Susceptibility

\section{INTRODUCTION}

Mastitis affects dairy production economically through its associated costs and effects on production (Peter et al., 2015; Martin et al., 2018). These costs may include: cost of drugs, reduced milk production and household income through discarding of milk in times of treatment, sudden death and premature culling of dairy cattle (Jingar et al., 2017). Mastitis also brings about changes in milk constituents due to the increase in somatic cells. These cells include; 
International Journal of Agriculture and Environmental Research

ISSN: 2455-6939

Volume: 06, Issue: 02 "March-April 2020"

polymorphonuclear neutrophils, macrophages, lymphocytes, and mammary epithelial cells (Jadhav et al., 2016). The numbers of these cells in milk are used as an indicator to monitor mammary gland health and their presence can be sign of mastitic conditions in the udders of dairy cattle. They are also used internationally to determine milk quality (Li et al., 2014; Jadhav et al., 2018). Dairy cows with robust immune systems always produce significant amounts of Somatic Cells in the milk (Teresiah et al., 2016; Jadhav et al., 2016).

However, in some instances, a high milk-producing breed of dairy cattle can produce a large number of somatic cell count due to inadequate milking and management. Mastitis is usually associated with a decline in the quantity produced and bacterial load in milk (Sharma et al., 2011; Azmi et al., 2017). The frequent use of antibiotic drugs in mastitis treatment and prevention results in their residues accumulation in animal bodies. These residues find their way into milk making it unfit for human consumption, and raising public health concerns (Jadhav et al., 2016).

Mastitis is a polygenic trait related to milk production, proteins, and milk quality traits. This it very complicated for molecular markers to be used in selective breeding for mastitis resistance breeds in dairy cattle (Tiezzil et al., 2015). Mastitis has low heritability as compared to SCC and SCS. This makes not suitable for selection of mastitis resistance. Selective breeding can help to lower the incidences of mastitis, when suitable candidate genes associated with mastitis resistance are identified (Cai et al., 2018).

Beta-lactoglobulin and lactoferrin genes have a bactericidal and bacteriostatic actions on pathogenic agents of mastitis. This study offers important insight into evaluation of genes associated with mastitis in crossbred cattle, and identify potential genetic markers that could be used for selection of mastitis resistance in order to improve milk quality.

\section{MATERIALS AND METHODS}

\subsection{DNA Samples}

About $5 \mathrm{ml}$ of blood samples were obtained aseptically from the external jugular vein of each of the 96 crossbred cattle dairy at Kanyariri Veterinary Farm for DNA analysis. Blood samples were placed into EDTA vacutainer tubes and transported under ice to a Molecular Genetics Laboratory at the Department of Animal Production (CAVS). The vacutainers were stored at $21^{\circ} \mathrm{C}$ prior to analysis. DNA was extracted from whole blood sample using QIAGEN DNA extraction kit (DNeasy® Blood \& Tissue kit), the manufacturer instructions were strictly followed.

\subsection{PCR Amplification for DNA templates}


International Journal of Agriculture and Environmental Research

ISSN: 2455-6939

Volume: 06, Issue: 02 "March-April 2020"

Optimization of PCR equipment were carried out prior to identify optimum temperature to be used (Baker et al.,2017). Two pairs of oligo primers were used for amplification of betalactoglobulin and lactoferrin genes respectively (Table 1). The amplification reaction was carried out in final volume of $25 \mu \mathrm{L}$, which was aggregated as $2 \mu \mathrm{L}$ (10x PCR buffer), $3 \mu \mathrm{L}$ (5x Q solution), $0.2 \mu \mathrm{L}$ of each primer, $0.4 \mu \mathrm{L}$ dNTPs mixture, $0.2 \mu \mathrm{L}$ Taq DNA polymerase, $15 \mu \mathrm{L}$ Nuclease-free water, and $4 \mu \mathrm{L}$ DNA template $(100 \mathrm{ng} / \mu \mathrm{L})$.

Table 1: Primer pairs used in the amplification of Beta-lactoglobulin and Lactoferrin genes respectively

\begin{tabular}{ll}
\hline Types of sequence & Primer sequence \\
\hline Oligo LGB - F & 5'- GTCCTTGTGCTGGACACCGACTACA -3' \\
Oligo LGB - R & 5'- CCCAGGACACCGGCTCCCGGTATAT-3' \\
\hline Oligo LTF - F & 5'- GCCTCATGACAACTCCCACAC -3 \\
Oligo LTF -R & 5'- CAGGTTGACACATCG GTTGAC -3' \\
\hline F -Forward Primer, R - Reverse Primer, Lactoglobulin (LGB) and Lactoferrin (LTF)
\end{tabular}

The reaction was performed in a thermal cycler (MJ RESEARCH, INC.) by Taq PCR Core kit 250 units (QIAGEN). The steps were; initialization at $94^{\circ} \mathrm{C}$ for 5 minutes, denaturation at $94^{\circ} \mathrm{C}$ for 60 seconds for 30 cycles, annealed at $61^{\circ} \mathrm{C}$ for 1 minute, extended at $72^{\circ} \mathrm{C}$ for 60 seconds. The final extension performed at $72^{\circ} \mathrm{C}$ for 7 minutes, and PCR products were stored at $4^{\circ} \mathrm{C}$ for betalactoglobulin (Sharma et al., 2015).

For lactoferrin reactions were carried out in thermal cycler (MJ RESEARCH, INC.) with the following conditions; initialization at $95^{\circ} \mathrm{C}$ for 5 minutes, denaturation at $95^{\circ} \mathrm{C}$ for 60 seconds followed by 35 cycles, annealing of primers at $57^{\circ} \mathrm{C}$ for 60 seconds, and extended at $72^{\circ} \mathrm{C}$ for 60 seconds. The final extension for both genes were was performed at $72^{\circ} \mathrm{C}$ for 7 minutes and PCR products were stored at $4^{\circ} \mathrm{C}$ (Azam et al., 2017). Its products were then subjected to $2 \%$ agarose gel electrophoresis at 100 volts for 40 minutes. The PCR products formed were viewed under ultraviolet transiluminator to its integrity, and photographed using a digital camera. The similar bands were for each gene and measured with DNA ladder 100bp plus (Kaplan, 2018).

\subsection{Sequences Analysis}

The BLAST was carried in NCBI results showed 85 to $100 \%$ resemblance to Bos Taurus, Bos Indicus and other species of cattle. The following accession numbers; MN239407 and MN239408 for Complement MN325091 to MN325104, and MN337970 to MN337991 were deposited in Genbank for beta-lactoglobulin and lactoferrin genes respectively. 


\section{RESULTS}

These phylogenetic tree was constructed by a maximum likelihoods and composed of functional taxonomic units of one node jointed to several others. The larger percentage of sequences of both beta-lactoglobulin and lactoferrin were found to be similar. The bootstrap consensus tree was replicated 1000 times to account for beta-lactoglobulin and lactoferrin genes. These sequences were compared with available sequences available in Genbank (Figure 2, \& 3).

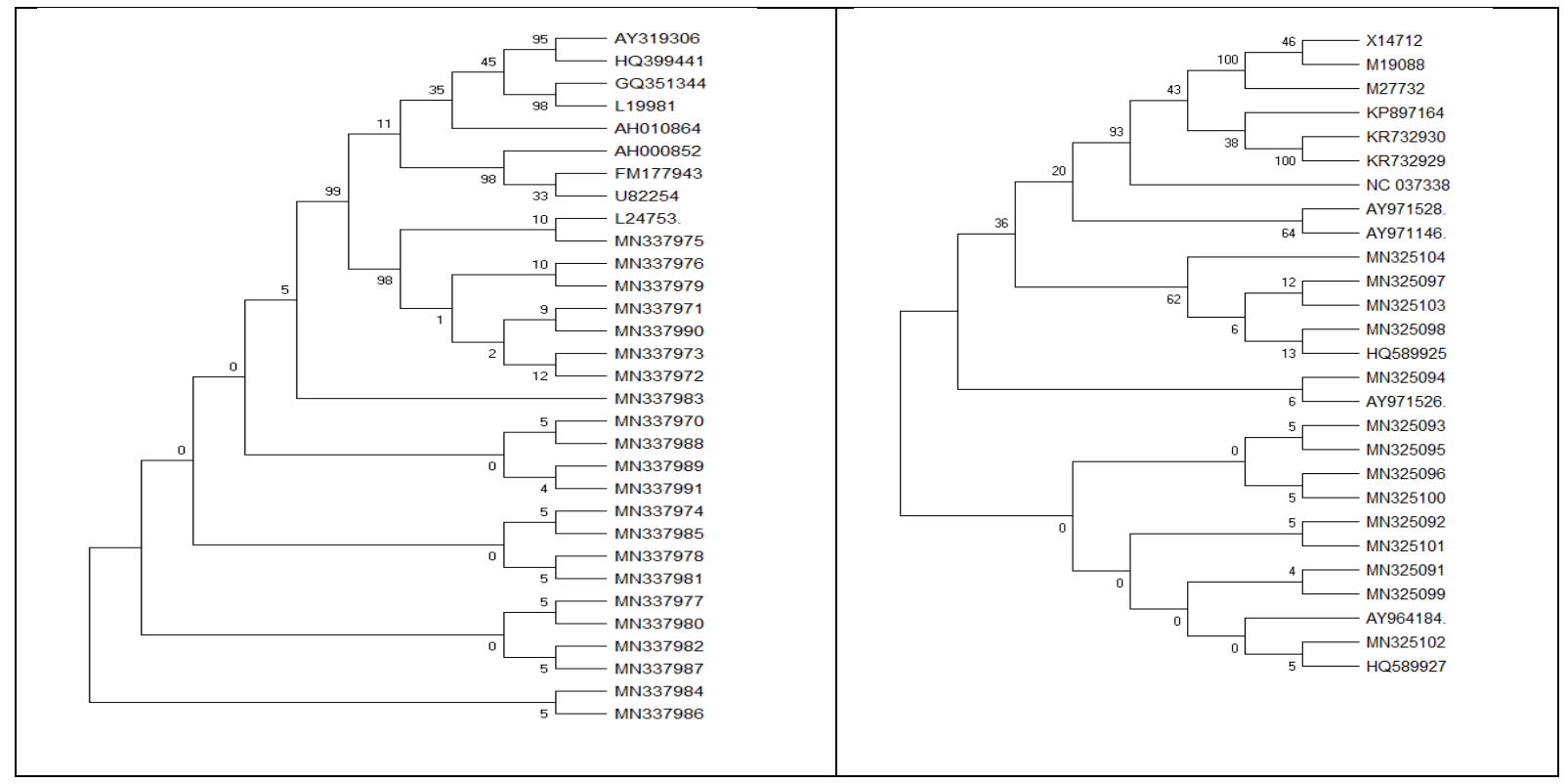

Figure $2 \&$ 3: phylogenetic tree constructed 5' flanking sequence of lactoferrin and betalactoglobulin respectively. Figures at nodes were represented by bootstrap values of 1000 replicates in data set.

The lactoferrin gene sequences were both homogenous and heterogeneous in nature for a population of 31 Nucleotide sequences. Beta-lactoglobulin gene composed of 27 sequences, which were aggregated into two larger lineages namely: (Clade 1 and 2) and (clade 3 and 4). These nucleotide sequences were clustered.

A total of 22 sequences of the lactoferrin gene were represented by their accession numbers in table 2 , sequences were varied between 50 to 100 positions within its flanking region. These sequences were derived from the sequenced PCR products of four main breeds of dairy cattle include; 
International Journal of Agriculture and Environmental Research

ISSN: 2455-6939

Volume: 06, Issue: 02 "March-April 2020"

In table 2 evaluation of genetic variability was carried out in between 50 to 100 base position. These genetic variants were identified as SNPs, which can be used as marker for selection of mastitis resistance dairy cattle. The polymorphisms found were both transitions and transversions in position include; A-G (50, 54 63, 67, and 98), G-A (50, 54, 63, 67, 96, and 98), C-T (63, 67, 69, 83, and 100), and T-C (69, 80, 83, 94, 96, 98, and 100); and A-C (50, 54, 63, 73, 75, 80, 83, 94, 96, and 100), C-A (63, 80, 83, 94, 96, and 100), G-C (50, 54, 63, 75, 83, 94, 96, and 98), C-G (50, and 63), A-T (54, 63, 67, 69, 80, 83, 94, 98, and 100), T-A (54, 63, 67, 75, 80, 94, and 96), G-T $(54,67,69,75,80$, and 98), and T-G $(67,69,80,83$, and 96) respectively.

Table 1: Accession Numbers for Different Sequences of Crossbred Dairy Cattle and Nucleotide base sequence variations from 50 to 100 base pairs for Lactoferrin gene.

\begin{tabular}{|c|c|c|c|c|c|c|c|c|c|c|c|c|}
\hline \multicolumn{13}{|c|}{ Nucleotide Base Positions Within The Sequences } \\
\hline ACESSION No. & 50 & 54 & 63 & 67 & 69 & 75 & 80 & 83 & 94 & 96 & 98 & 100 \\
\hline MN337970* & A & $\mathrm{G}$ & G & A & $\mathrm{G}$ & $\mathrm{T}$ & $\mathrm{T}$ & A & $\mathrm{C}$ & A & $\mathrm{C}$ & A \\
\hline MN337971* & $\mathrm{C}$ & $\mathrm{T}$ & $\mathrm{T}$ & $\mathrm{G}$ & $\mathrm{G}$ & A & A & $\mathrm{T}$ & A & $\mathrm{G}$ & $\mathrm{T}$ & $\mathrm{C}$ \\
\hline MN337972** & $\mathrm{G}$ & $\mathrm{T}$ & A & $\mathrm{T}$ & A & $\mathrm{T}$ & $\mathrm{C}$ & $\mathrm{C}$ & $\mathrm{C}$ & $\mathrm{C}$ & A & $\mathrm{T}$ \\
\hline MN337973* & A & A & A & $\mathrm{G}$ & $\mathrm{T}$ & $\mathrm{C}$ & $\mathrm{T}$ & A & $\mathrm{T}$ & $\mathrm{C}$ & $\mathrm{G}$ & $\mathrm{C}$ \\
\hline MN337974** & $\mathrm{C}$ & $\mathrm{C}$ & A & $\mathrm{C}$ & $\mathrm{T}$ & $\mathrm{G}$ & $\mathrm{G}$ & A & $\mathrm{T}$ & G & A & $\mathrm{C}$ \\
\hline MN337975* & A & A & $\mathrm{T}$ & A & G & $\mathrm{T}$ & $\mathrm{C}$ & G & $\mathrm{T}$ & $\mathrm{T}$ & A & A \\
\hline MN337976* & A & A & G & G & G & A & $\mathrm{G}$ & A & A & $\mathrm{C}$ & $\mathrm{C}$ & $\mathrm{C}$ \\
\hline MN337977** & $\mathrm{C}$ & $\mathrm{T}$ & $\mathrm{C}$ & $\mathrm{T}$ & A & $\mathrm{C}$ & $\mathrm{A}$ & $\mathrm{T}$ & $\mathrm{T}$ & A & $\mathrm{T}$ & A \\
\hline MN337978* & $\mathrm{C}$ & $\mathrm{G}$ & A & A & $\mathrm{G}$ & $\mathrm{G}$ & $\mathrm{T}$ & A & A & $\mathrm{T}$ & A & G \\
\hline MN337979* & A & $\mathrm{T}$ & A & G & $\mathrm{G}$ & $\mathrm{C}$ & A & A & A & A & $\mathrm{T}$ & $\mathrm{C}$ \\
\hline MN337980* & A & A & G & A & $\mathrm{C}$ & $\mathrm{T}$ & $\mathrm{C}$ & A & $\mathrm{C}$ & $\mathrm{C}$ & $\mathrm{T}$ & $\mathrm{G}$ \\
\hline MN337981* & $\mathrm{G}$ & $\mathrm{T}$ & $\mathrm{G}$ & $\mathrm{T}$ & $\mathrm{G}$ & $\mathrm{C}$ & $\mathrm{G}$ & $\mathrm{T}$ & A & A & $\mathrm{G}$ & A \\
\hline MN337982** & $\mathrm{T}$ & A & $\mathrm{T}$ & $\mathrm{G}$ & $\mathrm{T}$ & A & $\mathrm{T}$ & $\mathrm{T}$ & A & $\mathrm{C}$ & $\mathrm{C}$ & A \\
\hline MN337983** & A & $\mathrm{G}$ & $\mathrm{G}$ & A & $\mathrm{G}$ & $\mathrm{T}$ & A & A & $\mathrm{C}$ & A & $\mathrm{C}$ & A \\
\hline MN337984** & $\mathrm{C}$ & $\mathrm{C}$ & $\mathrm{T}$ & $\mathrm{T}$ & $\mathrm{C}$ & $\mathrm{C}$ & $\mathrm{T}$ & $\mathrm{C}$ & A & A & $\mathrm{G}$ & $\mathrm{C}$ \\
\hline MN337985** & G & A & A & A & $\mathrm{T}$ & $\mathrm{T}$ & G & $\mathrm{G}$ & $\mathrm{C}$ & A & $\mathrm{C}$ & A \\
\hline MN337986* & $\mathrm{G}$ & $\mathrm{C}$ & $\mathrm{G}$ & $\mathrm{T}$ & $\mathrm{T}$ & A & $\mathrm{T}$ & $\mathrm{T}$ & $\mathrm{C}$ & $\mathrm{C}$ & $\mathrm{C}$ & $\mathrm{T}$ \\
\hline MN337987* & $\mathrm{C}$ & $\mathrm{C}$ & $\mathrm{T}$ & $\mathrm{T}$ & A & $\mathrm{T}$ & $\mathrm{T}$ & A & $\mathrm{G}$ & $\mathrm{C}$ & A & A \\
\hline MN337988* & $\mathrm{C}$ & $\mathrm{G}$ & A & $\mathrm{A}$ & $\mathrm{G}$ & $\mathrm{G}$ & $\mathrm{T}$ & $\mathrm{A}$ & $\mathrm{T}$ & $\mathrm{C}$ & A & $\mathrm{G}$ \\
\hline MN337989* & A & $\mathrm{T}$ & $\mathrm{G}$ & A & $\mathrm{G}$ & $\mathrm{T}$ & A & $\mathrm{T}$ & $\mathrm{G}$ & $\mathrm{G}$ & $\mathrm{A}$ & $\mathrm{C}$ \\
\hline MN337990* & A & $\mathrm{G}$ & $\mathrm{C}$ & A & A & $\mathrm{T}$ & $\mathrm{T}$ & $\mathrm{A}$ & A & $\mathrm{G}$ & $\mathrm{T}$ & $\mathrm{C}$ \\
\hline MN337991* & $\mathrm{C}$ & A & A & $\mathrm{G}$ & A & A & A & A & $\mathrm{C}$ & A & $\mathrm{C}$ & $\mathrm{G}$ \\
\hline
\end{tabular}

* Healthy cows 
International Journal of Agriculture and Environmental Research

ISSN: 2455-6939

Volume: 06, Issue: 02 "March-April 2020"

A total of 14 sequences represented by their accession numbers deposited in Genbank (table 3). These sequence were found to varied between 9 to 195 positions. These polymorphisms were AG (136, 159, and 165), G-A (165, 174), C-T (9, 138), T-C (32); and C-A (136, 159, 163), G-C (9, 14), C-G (116, 138, 138, 163), G-T (9, 136, 138), T-G (32) in transitions and transversions position respectively. These polymorphisms were found to be highly associated to mastitis susceptibility. Thus, these can be applied as markers in associate studies.

Table 2: Accession Numbers for Different Sequences of Crossbred Dairy Cattle and Nucleotide base variations from 09 to 195 base pairs for the beta-lactoglobulin gene

\begin{tabular}{|c|c|c|c|c|c|c|c|c|c|c|c|c|}
\hline \multicolumn{13}{|c|}{ NUCLEOTIDE POSITION WITHIN THE SEQUENCE } \\
\hline Accession No. & 9 & 14 & 32 & 116 & 136 & 138 & 159 & 163 & 165 & 174 & 178 & 195 \\
\hline MN325091* & G & G & G & G & A & $\mathrm{C}$ & $\mathrm{G}$ & G & G & G & $\mathrm{C}$ & G \\
\hline MN325092* & G & $\mathrm{G}$ & $\mathrm{G}$ & $\mathrm{G}$ & A & $\mathrm{C}$ & $\mathrm{G}$ & $\mathrm{G}$ & $\mathrm{G}$ & $\mathrm{G}$ & $\mathrm{C}$ & $\mathrm{G}$ \\
\hline MN325093* & $\mathrm{C}$ & $\mathrm{G}$ & $\mathrm{T}$ & $\mathrm{T}$ & $\mathrm{C}$ & $\mathrm{G}$ & $\mathrm{C}$ & $\mathrm{G}$ & A & $\mathrm{G}$ & $\mathrm{G}$ & $\mathrm{G}$ \\
\hline MN325094* & $\mathrm{T}$ & $\mathrm{G}$ & $\mathrm{C}$ & $\mathrm{G}$ & G & $\mathrm{G}$ & A & G & A & $\mathrm{G}$ & $\mathrm{C}$ & A \\
\hline MN325095** & $\mathrm{T}$ & $\mathrm{C}$ & $\mathrm{C}$ & $\mathrm{G}$ & $\mathrm{G}$ & $\mathrm{G}$ & A & G & A & $\mathrm{G}$ & $\mathrm{C}$ & A \\
\hline MN325096** & $\mathrm{C}$ & $\mathrm{C}$ & G & $\mathrm{T}$ & $\mathrm{T}$ & $\mathrm{T}$ & $\mathrm{C}$ & A & A & A & A & $\mathrm{T}$ \\
\hline MN325097* & $\mathrm{C}$ & $\mathrm{G}$ & $\mathrm{G}$ & $\mathrm{G}$ & G & $\mathrm{G}$ & A & G & $\mathrm{G}$ & $\mathrm{T}$ & $\mathrm{C}$ & $\mathrm{G}$ \\
\hline MN325098* & G & $\mathrm{G}$ & G & $\mathrm{G}$ & A & $\mathrm{C}$ & G & $\mathrm{G}$ & $\mathrm{G}$ & $\mathrm{G}$ & $\mathrm{C}$ & G \\
\hline MN325099* & G & $\mathrm{C}$ & G & $\mathrm{G}$ & A & $\mathrm{C}$ & $\mathrm{G}$ & G & $\mathrm{G}$ & $\mathrm{G}$ & $\mathrm{C}$ & $\mathrm{G}$ \\
\hline MN325100* & $\mathrm{C}$ & G & $\mathrm{T}$ & $\mathrm{T}$ & $\mathrm{C}$ & $\mathrm{G}$ & $\mathrm{C}$ & G & A & $\mathrm{G}$ & $\mathrm{G}$ & $\mathrm{G}$ \\
\hline MN325101** & G & G & G & G & A & G & G & G & G & $\mathrm{G}$ & $\mathrm{C}$ & $\mathrm{G}$ \\
\hline MN325102** & G & G & G & G & A & $\mathrm{C}$ & G & $\mathrm{C}$ & G & $\mathrm{G}$ & $\mathrm{C}$ & $\mathrm{G}$ \\
\hline MN325103* & G & $\mathrm{G}$ & G & $\mathrm{G}$ & A & $\mathrm{C}$ & G & G & G & $\mathrm{G}$ & $\mathrm{C}$ & $\mathrm{G}$ \\
\hline MN325104* & G & G & $\mathrm{G}$ & $\mathrm{G}$ & A & $\mathrm{C}$ & $\mathrm{G}$ & $\mathrm{G}$ & $\mathrm{G}$ & $\mathrm{G}$ & $\mathrm{C}$ & $\mathrm{G}$ \\
\hline
\end{tabular}

* Healthy cows

** Subclinical Mastitis

\section{DISCUSSION}

The 5'flanking region of lactoferrin gene harbours genetic polymorphisms, which significantly attributes to its sequence genetic variabilities, this statement was agreement with (Sharma et al., 2015; Ateya et al., 2016). This property largely contributes to diverse actions of the gene on micro-organisms, through iron binding nature of the gene which deprives mastitis causal agents 
International Journal of Agriculture and Environmental Research

ISSN: 2455-6939

Volume: 06, Issue: 02 "March-April 2020"

iron needed for their growth. On other hands, bactericidal and bacteriostatic nature of lactoferrin gene on micro-organisms, has made it appropriate candidate gene for selection for mastitis resistance. Thus, its flanking region are sometimes referred as flanking SNPs and also associated with the presence of mastitis and SCC in milk (Yuan et al.,2013; Pawlik et al., 2014; Ateya et al.,2016).

The production of lactoferrin gene in udder quarter is triggered by presence of infections, which prompts into an increase in number of cells which include; neutrophil which at some time produces lactoferrin gene in milk. The diverse nature of the regulatory region of lactoferrin gene with presence of the promoter sequences, TATA box, and multiple transcription binding sites, made it suitable gene to be used in genetic selection of mastitis resistance (Zabolewicz et al.,2012; Zabolewicz et al.,2014).

Beta-lactoglobulin gene is a vital whey protein in milk. It has iron-binding, antibacterial and its inhibitory nature, which affects the growth of mastitis causing agents in milk such as; Staphylococcus ssp, Staphylococcus ssp and many others. This reduces their populations in the udder, thus improves milk quality to be consumed by human (Chaneton et al., 2010; Ateya et al.,2016; Martin et al.,2018). The presence of mastitis causal agents in udder quarter triggers an increase of SCC in milk, which eventually are used to monitor udder health in dairy cows (Singh et al.,2014). The application of SCC as monitor for udder's health status is simple, affordable and it can be handled by smallholder dairy farmers without expertise supports. Early detection of subclinical mastitis is essential to maximize their profits through reduction of the cost of disease control and prevention.

This gene was found out to be highly polymorphic at the following positions in its sequences; AG (136, 159, and 165), G-A (165, 174), C-T (9, 138), T-C (32); and C-A (136, 159, 163), G-C (9, 14), C-G $(116,138,138,163)$, G-T $(9,136,138)$, T-G (32) in transitions and transversions position respectively. Table 3 these polymorphisms play tremendous roles in regulating the growth and multiplications of pathogenic agents and maintaining the quality of milk against bacterial. Furthermore, the inhibitory nature of these genes reinforce mammary gland immune mechanics, when the innate immune system is impaired. This provides a faster, more efficient, and timely defence against intra-mammary gland infections (Lukač et al., 2013; Ateya et al.,2016). Thus, reduces bacterial loads present in milk. This action triggers an increase in SCC in milk, as a result of immune response mechanism. Therefore, it plays a key role in addressing challenges imposed by mastitis, and it can be to used improve animal milk safety and increase milk production.

Figures 1 and 2 suggested that there were gene flows between these admixed breeds of dairy cows. This study does not reject the incidences of incongruence among the sequences (Tak et 
International Journal of Agriculture and Environmental Research

ISSN: 2455-6939

Volume: 06, Issue: 02 "March-April 2020"

al., 2018). The genetic polymorphisms in the DNA remains variable from one sequence to another sequence. Breed differences were due to an individual genetic made up, and this supported the argument that genotype and allele frequencies remain variable from one population to another (Boushaba et al., 2019). However, the similarity between the sequences were attributed by Artificial Insemination (AI), which allows easy gene flow and lessens the mating barrier between several breeds of dairy cattle. This was in line with Smiltina \& Grislis, 2018; Tak et al., 2018).

\section{CONCLUSIONS}

The study found out significant associations among beta-lactoglobulin, lactoferrin genes and somatic cell counts, these manifested mainly in udder quarters of dairy cows positive for subclinical mastitis. The sequences of two genes were also found to be related with other sequences of Bos Taurus, Bos Indicus and other breeds of cattle dairy in globally. This study also mitigates problems related to milk quality as far as mastitis is concerned, which in turn aids hygienic milk fit for human consumption.

\section{ACKNOWLEDGEMENT}

This material is based upon work supported by the United States Agency for International Development (USAID), as part of the Feed the Future initiative, under the CGIAR Fund, award number BFS-G-11-00002, and the predecessor fund the Food Security and Crisis Mitigation II grant, award number EEM-G-00-04-00013.

\section{REFERENCES}

1. Ateya, A. I., El-Seady, Y. Y., Atwa, S. M., Merghani, B. H., \& Sayed, N. A. Novel single nucleotide polymorphisms in lactoferrin gene and their association with mastitis susceptibility in holstein cattle. Genetika. 2016; 48(1), pp. 199-210.

2. Azam, M., Abu, A., Rovie-ryan, J. J., Resources, N., Ampeng, A., \& Yaakop, S. optimisation of polymerase chain reaction conditions to amplify d-loop region in the malaysian mousedeer genomic DNA Optimisation of Polymerase Chain Reaction conditions to amplify d-loop region in the. December), 2017.

3. Azmi, A., Umam, K., Lin, M., \& Radiati, L. E. Study on The Bulk Milk Somatic Cell Counts and Milk Quality in Different Seasons. Scholars Journal of Agriculture and Veterinary Sciences. 2017; 4(11), pp. 498-503.

4. Bakar, M. A. A. A., Rovie-Ryan, J. J., Ampeng, A. H. M. A. D., Yaakop, S., Nor, S. M., \& Md-Zain, B. M. Optimisation of polymerase chain reaction conditions to amplify D-LOOP region in the Malaysian mousedeer genomic DNA. Malays Appl Biol, 46, pp. 63-71, 2017.

5. Boushaba, N., Boujenane, I., Moazami-Goudarzi, K., Flori, L., Saïdi-Mehtar, N., Tabet- 
International Journal of Agriculture and Environmental Research

ISSN: 2455-6939

Volume: 06, Issue: 02 "March-April 2020"

Aoul, N., \& Laloë, D. Genetic diversity and relationships among six local cattle populations in semi-arid areas assessed by a bovine medium-density single nucleotide polymorphism data. Animal, 13(1), pp. 8-14, 2019.

6. Cai, Z., Guldbrandtsen, B., Lund, M. S., \& Sahana, G. Prioritizing candidate genes postGWAS using multiple sources of data for mastitis resistance in dairy cattle. BMC Genomics, 19(1), pp. 1-11, 2018.

7. Chaneton, L., Pérez Sáez, J. M., \& Bussmann, L. E. Antimicrobial activity of bovine $\beta$ lactoglobulin against mastitis-causing bacteria. Journal of Dairy Science. 2010; 94(1), 138145.

8. Jadhav, P. V., Tarate, S. B., Bhuvana, M., Das, D. N., \& Shome, B. R. Somatic cell count as a monitoring system for hygienicmilk production in India: A review. Asian Journal of Dairy and Food Research, 35(4), pp. 270-277, 2016.

9. Jadhav, P. V., Das, D. N., Suresh, K. P., \& Shome, B. R. Threshold somatic cell count for delineation of subclinical mastitis cases. Veterinary world, 11(6), pp. 789, 2018.

10. Jingar, S. C., Mahendra, S., \& Roy, A. K. Economic losses due to clinical mastitis in crossbred cows. J. Dairy Vet. Sci, 3(2), 2017. 497-505.

11. Kaplan, S. Nucleotide sequence variations of lactoferrin gene in anatolian water buffaloes. fresenius environmental bulletin, 27(9), pp. 6427-6432, 2018.

12. Li, N., Richoux, R., Boutinaud, M., Martin, P., \& Gagnaire, V. Role of somatic cells on dairy processes and products: A review. Dairy Science and Technology, 94(6), pp. 517538, 2014.

13. Lukač, D., Vidović, V., Stupar, M., Popović-Vranješ, A., \& Nemeš, Ž. Genotypic frequencies of the $\beta$-lactoglobulin, $\kappa$-casein and transferrin in Serbian Holstein-Friesian dairy cattle. Mljekarstvo, 63(4), pp. 203-210, 2013.

14. Martin, P., Barkema, H. W., Brito, L. F., Narayana, S. G., \& Miglior, F. Symposium review: Novel strategies to genetically improve mastitis resistance in dairy cattle. Journal of Dairy Science, 101(3), pp. 2724-2736, 2018.

15. Pawlik, A., Sender, G., Sobczynska, M., Korwin-Kossakowska, A., Oprzadek, J., \& Lukaszewicz, M. Association between lactoferrin single nucleotide polymorphisms and milk production traits in Polish Holstein cattle. Archives Animal Breeding, 57(1), pp.1-12, 2014.

16. Peters, M. D. P., Silveira, I. D. B., \& Fischer, V. Impact of subclinical and clinical mastitis on sensitivity to pain of dairy cows. Animal, 9(12), pp. 2024-2028, 2015.

17. Sharma, N., Singh, N. K., \& Bhadwal, M. S. Relationship of somatic cell count and mastitis: An overview. Asian-Australasian Journal of Animal Sciences, 2011, 24(3), 429438.

18. Sharma, R., Chakraborty, D., \& Gupta, P. Bovine lactoferrin and its functions in animals-A 
International Journal of Agriculture and Environmental Research

ISSN: 2455-6939

Volume: 06, Issue: 02 "March-April 2020"

review. Agricultural Reviews, 2015, 36(4).

19. Sharma, P., Parmar, S. N. S., Thakur, M. S., Nauriyal, D. S., \& Ranjan, R. Association of Bovine Lactoferrin Gene with Mastitis in Frieswal Cattle. Iranian Journal of Applied Animal Science, 2015, 5(4), 859-863.

20. Singh, U., Deb, R., Alyethodi, R. R., Alex, R., Kumar, S., Chakraborty, S., ... Sharma, A. Molecular markers and their applications in cattle genetic research: A review. Biomarkers and Genomic Medicine, 2014, 6(2), 49-58.

21. Singh, U., Deb, R., Kumar, S., Singh, R., Sengar, G., \& Sharma, A. Association of prolactin and beta-lactoglobulin genes with milk production traits and somatic cell count among Indian Frieswal (HF×Sahiwal) cows. Biomarkers and Genomic Medicine, 2015, 7(1), 38-42.

22. Smiltina, D., \& Grislis, Z. Molecular genetics analysis of milk protein gene polymorphism of dairy cows and breeding bulls in Latvia. Agronomy Research, 2018, 16(3), 900-909.

23. Tak, K. H., Yu, G. I., Lee, M. Y., \& Shin, D. H. Association Between Polymorphisms of Interleukin 1 Family Genes and Hepatocellular Carcinoma. Medical Science Monitor, 2018, 24, 3488-3495.

24. Teresiah, W. N., Patrick, S. M., Mary, O., Gerard, O., \& Anton, J. Quality control of raw milk in the smallholder collection and bulking enterprises in Nakuru and Nyandarua Counties, Kenya. African Journal of Food Science, 2016, 10(5), 70-78.

25. Tiezzil, F., Parker-Gaddis, K. L., Cole, J. B., Clay, J. S., \& Maltecca, C. A genome-wide association study for clinical mastitis in first parity US Holstein cows using single-step approach and genomic matrix re-weighting procedure. PLoS ONE, 2015, 10(2), 1-15.

26. Yuan, Z., Li, J., Li, J., Gao, X., \& Xu, S. SNPs identification and its correlation analysis with milk somatic cell score in bovine MBL1 gene. Molecular biology reports, 2013, 40(1), 7-12.

27. Zabolewicz, T., Barcewicz, M., Brym, P., Puckowska, P., \& Kamiński, S. Association of polymorphism within LTF gene promoter with lactoferrin concentration in milk of Holstein cows. Polish Journal of Veterinary Sciences,2014, 17(4), 633-641.

28. Zabolewicz, Tadeusz, Brym, P., Olenski, K., Suchocki, T., Malewski, T., Szyda, J., \& Kaminski, S. Polymorphism within TATA-box of bovine lactoferrin gene and its association with performance traits in Holstein cattle. Livestock Science, 2012, 149(3), $267-274$. 